\title{
Synergistic Impacts of Climate Change and Human Activities on Spatiotemporal Organic Nitrogen Burial Variation in a Plateau Lake in Southwest China
}

\author{
Yang Luo \\ Nanjing Normal University \\ Quanliang Jiang \\ Nanjing Normal University \\ Zhigang Zhang \\ Nanjing Normal University \\ Hao Yang \\ Nanjing Normal University \\ Changchun Huang \\ Nanjing Normal University
}

Tao Huang ( $\square$ huangtao198698@126.com )

Nanjing Normal University https://orcid.org/0000-0003-4237-7087

\section{Research Article}

Keywords: Organic nitrogen, n-alkanes, Dianchi Lake, STIRPAT model, human activities, algal blooms

Posted Date: September 14th, 2021

DOI: https://doi.org/10.21203/rs.3.rs-811547/v1

License: (1) (i) This work is licensed under a Creative Commons Attribution 4.0 International License.

Read Full License 


\section{Abstract}

The concentration and sources of organic nitrogen (ON) in lake sediment significantly affect the lake nitrogen cycle. However, the influencing factors and contributors to the $\mathrm{ON}$ accumulation rate $\left(\mathrm{ON}_{\mathrm{AR}}\right)$ are unclear. In this study, tree sediment cores from northern, eastern, and southern Dianchi Lake (DC-N, DC-E, and DC-S, respectively), sampled in July 2014, were used to study the effects of autochthonous and allochthonous sources on $\mathrm{ON}$. The results showed that $\mathrm{ON}$ and the $\mathrm{ON}_{\mathrm{AR}}$ increased 2.4-5.1 and 2.6-4.8 times, respectively, from 1900 to 2000 , especially since the 1980 s, at which point algal blooms occurred more frequently. The ON contents decreased in the order: $D C-S>D C-N>D C-E$, whereas the $\mathrm{ON}_{A R}$ values followed the order: $\mathrm{DC}-\mathrm{N}>\mathrm{DC}-\mathrm{S}>\mathrm{DC}-\mathrm{E}$, suggesting that the $\mathrm{ON}_{\mathrm{AR}}$ was influenced by $\mathrm{ON}$ content as well as depositional environmental conditions. The total concentrations of $n$-alkanes $\left(n-\mathrm{C}_{12}\right.$ to $n$ - $\left.\mathrm{C}_{34}\right)$ ranged from $4719.4 \mathrm{ng} \mathrm{g}^{-1}$ to $61,959.6 \mathrm{ng} \mathrm{g}^{-1}$ in the three sediment cores, each of which exhibited different $n$-alkanes characteristic variation with vertical depth. The sources of ON were mainly allochthonous (soil erosion and terrestrial plants) and autochthonous (algal and aquatic plants) in DC-S and DC-N, respectively, whereas they were primarily mixed planktonic and terrestrial sources in DC-E. Using the stochastic impacts by regression on population, affluence, and technology model to further examine the $O \mathrm{~N}_{\mathrm{AR}}$ values revealed that $1 \%$ increase in temperature and nitrogen fertilizer can increase the $\mathrm{ON}_{\mathrm{AR}}$ by $73.8-86.2 \%$ and 73.2-151.3\% in all sediments, especially in DC-S and DC-E. However, a 1\% increase in construction area could reduce the $\mathrm{ON}_{\mathrm{AR}}$ by $2.4-14.2 \%$, especially in DC-N. Overall, climate change and human activities determine the spatial and temporal $\mathrm{ON}_{\mathrm{AR}}$ variation in Dianchi Lake.

\section{Introduction}

Nitrogen is a limiting factor for the primary production of ecosystems, and has become a hot topic in climate change research over the past few decades (Galloway et al., 2008; Fowler et al., 2013). Lacustrine deposits play a vital role in overall nutrient cycling in lakes, especially regarding the nitrogen cycle (Elser et al., 2007; Conley et al., 2009). Lacustrine nitrogen has many forms with different biogeochemical characteristics. Sedimentary organic nitrogen $(\mathrm{ON})$ is the main form of nitrogen. It accumulates in the sediment and is easily converted to nitrate and ammonia via mineralization. Most of the converted ammonium and nitrate are released into the overlying water, which may cause algal blooms (Galman et al., 2008; Yu et al., 2018). The effects of algal residues, which are considered important autochthonous sources, on organic matter burial have been widely studied (Anderson et al., 2014; Leithold et al., 2016). Overall, while carbon is a major element in organic matter and has been widely reported, research concerning nitrogen is limited.

Recent studies have proposed that the sources of sedimentary ON are very complex and include municipal sewage, agricultural fertilizer, bacteria, and algae, terrestrial and aquatic plants and so on (Leithold et al., 2016; Wang et al., 2020). In addition, most previous studies have found that the hydrological characteristics, including trophic state, climate, and vegetation, in lake watersheds affect organic matter accumulation in sediment (Downing et al., 2008; Anderson et al., 2013; Anderson et al., 2014). For 
instance, Heathcote et al. (2015) revealed that climate change could significantly increase organic carbon accumulation in northern lakes. However, most previous research has focused on boreal lakes, while some have focused on temperate-zone lakes to determine the burial efficiency and influencing factors of organic matter burial over different time scales (Anderson et al., 2013; Anderson et al., 2014; Heathcote et al., 2015; Fortino et al., 2016; Jiang et al., 2020). Since 1970, Dianchi Lake, which is the largest sub-tropic plateau lake in Southwest China, has not only been affected by a variety of climatic features (such as monsoons, high-altitude, and low-latitude climates) but also by eutrophication and intensive human activities (such as deforestation, urbanization, and fertilization) (Gao et al., 2015; Huang et al., 2017b; Chen et al., 2020). Eutrophication is considered to be an important driver of increasing organic carbon as a result of not only the enrichment of nutrients in lake water but also perennial climate change (Larsen et al., 2011; Chen et al., 2020). Therefore, the effect of human activities on the spatial and temporal sediment $O N$ accumulation rate $\left(\mathrm{ON}_{\mathrm{AR}}\right)$ could provide a comprehensive understanding of the lake nitrogen cycle under climate change.

$\mathrm{N}$-alkanes, widely present in bacteria, algae, aquatic, and terrestrial plants, are considered to be an ideal biomarker for tracing the source of organic matter under environmental and climatic changes because of their degradation resistance (Mead et al., 2005; Fang et al., 2014; Liu and Liu, 2016). The distribution of the $n$-alkanes carbon content in bacteria and algae ranges from $n-\mathrm{C}_{15}$ to $n$ - $\mathrm{C}_{20}$. The $n$-alkanes distribution in aquatic macrophytes and crude oil is dominated by mid-chain alkanes $\left(n-\mathrm{C}_{20}\right.$ to $\left.n-\mathrm{C}_{25}\right)$. Terrestrial higher plants are typically characterized by a high abundance of long-chain $n$-alkanes ( $n-C_{27}$ to $\left.n-C_{33}\right)$ (Ficken et al., 2000; Liu and Liu, 2016). Complex relationships exist between climate change and human activities, which obscure the effect of individual factors on ON burial. The stochastic impacts by regression on population, affluence, and technology (STIRPAT) model can be used to statistically analyze the non-monotonic or non-proportional impacts of driving factors on the environment (Dietz, 1994; York et al., 2003). It has been successfully utilized to explore the influence of human factors and analyze the effects of driving forces on a variety of environments, including carbon dioxide emissions and environmental changes (Wang et al., 2013; Zhou and Liu, 2016).

Therefore, in this study, we combined chronology and $n$-alkanes indicators to explore the contributions of autochthonous and allochthonous to ON sources in various regions of Dianchi Lake over different periods. In addition, we quantitatively evaluated the effects of climate change and human activities on sedimentary ON burial in different regions of Dianchi Lake using the STIRPAT model.

\section{Materials And Methods}

\subsection{Study area}

Dianchi Lake $\left(24^{\circ} 40^{\prime}-25^{\circ} 02^{\prime} \mathrm{N}, 102^{\circ} 36^{\prime}-102^{\circ} 47^{\prime} \mathrm{E}\right)$ is located in the Yunnan Province in southwest China and has an average altitude of $1886 \mathrm{~m}$. It is the largest lake in the Yunnan Province and the sixth-largest freshwater lake in China. More than 20 rivers flow into Dianchi Lake, while only one river flows out. The climate is subtropical, humid, and monsoonal. The annual mean temperature is $14.8^{\circ} \mathrm{C}$. The rainy season 
occurs from May to October, contributing an average annual rainfall of $1000 \mathrm{~mm}$. Red and purple soils are the main soil types around Dianchi Lake. The average and maximum water depths in Dianchi Lake are 5.1 $\mathrm{m}$ and $10.9 \mathrm{~m}$, respectively. Dianchi Lake has a storage capacity of 1.57 billion $\mathrm{m}^{3}$ and a total area of 309 $\mathrm{km}^{2}$. The land use of the $2800 \mathrm{~km}^{2}$ lake basin is mainly forest (35.71\%), agriculture (22.95\%), and construction (28.55\%).

\subsection{Sample collection and analysis of nitrogen and carbon}

Three sediment cores (DC-S, DC-E, and DC-N) were collected from three locations in diverse regions of Dianchi Lake using a gravity corer in July 2014 (Fig. 1). These cores, DC-S, DC-E, and DC-N, were located in the southern, eastern, and northern regions of Dianchi Lake, respectively. For each core, sediments were subsampled at $1 \mathrm{~cm}$ intervals, frozen, and then freeze-dried.

Total nitrogen (TN) was determined after digestion using persulfate $\left(\mathrm{K}_{2} \mathrm{~S}_{2} \mathrm{O}_{4}+\mathrm{NaOH}\right)$ at $121^{\circ} \mathrm{C}$ for 30 min. To determine the $\mathrm{NH}_{4}-\mathrm{N}$ and $\mathrm{NO}_{3}-\mathrm{N}$ contents, 2 mol L-1 $\mathrm{KCl}$ was added to the samples and then shaken for $30 \mathrm{~min}$. The filtrate was then extracted using a $0.45 \mu \mathrm{m}$ membrane filter. $\mathrm{NO}_{3}-\mathrm{N}$ was directly determined using a UV-3600 spectrophotometer (Shimadzu Corp., Japan). The $\mathrm{NH}_{4}-\mathrm{N}$ content was analyzed using salicylic acid and hypochlorous acid salt spectrophotometry. The $\mathrm{ON}$ concentration was obtained by subtracting the inorganic nitrogen content, which includes $\mathrm{NH}_{4}-\mathrm{N}$ and $\mathrm{NO}_{3}-\mathrm{N}$, from the TN content. Total organic carbon (TOC) was measured using a total organic carbon analyzer (Shimadzu Corp., Japan).

\section{3 n-alkanes determination and source identification}

$n$-alkanes were extracted from a $2 \mathrm{~g}$ subsample using microwave extraction $\left(100^{\circ} \mathrm{C}, 10 \mathrm{~min}\right)$ with a dichloromethane-methanol mixed solution (93:7, v: v) (Mead et al., 2005; Fang et al., 2014). The supernatant was obtained after completing the extraction after three centrifugations. The solvent was replaced with $\mathrm{n}$-hexane and concentrated to $1 \mathrm{~mL}$ three times via rotary evaporation at $40^{\circ} \mathrm{C}$. The concentrated solution was separated and purified by solid-phase extraction and concentrated to $1 \mathrm{~mL}$ via rotary evaporation. The $n$-alkanes were quantified by measuring the concentration of the fluent via gas chromatography-mass spectrometry (GC/MS-QP2010 Ultra, Shimadzu Corp. Japan). For this, the injection port temperature was gradually increased to $300^{\circ} \mathrm{C}$ at a rate of $10^{\circ} \mathrm{C} \mathrm{min}-1$ from its starting temperature of $50^{\circ} \mathrm{C}$.

The proxy of aquatic macrophyte input (Paq) and carbon preference index (CPI) are useful for identifying the sources of $n$-alkanes. Paq represents the proportion of $n$-alkanes in submerged plants among the midchain and long-chain $n$-alkanes. Meanwhile, the CPI is widely used as a source indicator of $n$-alkanes. Their calculations are as follows:

$C P I_{1}=\frac{1}{2} \times\left(\sum \operatorname{odd}\left(C_{15}-C_{23}\right) / \operatorname{even}\left(C_{14}-C_{23}\right)\right)+\left(\sum \operatorname{odd}\left(C_{15}-C_{23}\right) / \operatorname{even}\left(C_{16}-C_{24}\right)\right)$, 
$C P I_{2}=\frac{1}{2} \times\left(\sum \operatorname{odd}\left(C_{25}-C_{33}\right) / \operatorname{even}\left(C_{24}-C_{32}\right)\right)+\left(\sum \operatorname{odd}\left(C_{25}-C_{33}\right) / \operatorname{even}\left(C_{26}-C_{34}\right)\right)$,

$$
\text { Paq } \left.=\left(C_{23}+C_{25}\right) / C_{23}+C_{25}+C_{29}+C_{31}\right)
$$

3.

$C n$ represents different carbon numbers of $n$-alkanes. $N$-alkanes derived from land plants showed a predominance of odd-numbered carbon chains with $\mathrm{CPI}_{2}\left(\mathrm{CPI}_{25}\right.$ 33 $)$, while $\mathrm{CPI}_{1}\left(\mathrm{CPI}_{15 \sim 23}\right)$ values close to 1 with the preference of $n-\mathrm{C}_{15}$ or $n-\mathrm{C}_{17}$ may indicate a greater input from floating aquatic plants(Liu and Liu, 2016; Wang et al., 2019).

\subsection{Chronology and accumulation rates of ON}

The ${ }^{210} \mathrm{~Pb}$ radiometric technique has been used to analyze sediment chronologies (Smith, 2001; SanchezCabeza and Ruiz-Fernandez, 2012). Herein, a high-resolution HPGe $\gamma$-spectrometer (EG\&GORTEC, GWL$120-15$, USA) was used to determine the activities of ${ }^{226} \mathrm{Ra}$ and ${ }^{210} \mathrm{~Pb}$ at a $40,000 \mathrm{~s}$ determination time. The difference between ${ }^{226} \mathrm{Ra}$ and ${ }^{210} \mathrm{~Pb}$ is the activity of excess ${ }^{210} \mathrm{~Pb}\left({ }^{210} \mathrm{~Pb}_{\mathrm{ex}}\right)$. After determination, a constantrate of ${ }^{210} \mathrm{Pbsupply}$ model was applied to date the sediment cores (Eq. (4)). The distribution of $\mathrm{Pb}_{\mathrm{ex}}$ and the dating of the three sediment cores are detailed in Huang et al. (2017b).

$\mathrm{T}_{\mathrm{h}}=\mathrm{T}_{0}-\ln \left(\mathrm{A}_{0} / \mathrm{A}_{\mathrm{h}}\right) / \lambda,(4)$

where $T_{0}$ is the sampling year (i.e., 2014), $\lambda$ is the decay constant of ${ }^{210} \mathrm{~Pb}\left(0.03114\right.$ year $\left.^{-1}\right), A^{2} A_{0}$ and $\mathrm{A}_{h}$ are the inventories of ${ }^{210} \mathrm{~Pb}_{\mathrm{ex}}$ for the entire core and the section below depth $h\left(\mathrm{~Bq} \mathrm{~cm}^{-2}\right)$, respectively. The $\mathrm{ON}_{\mathrm{AR}}\left(\mathrm{g} \mathrm{cm}^{-2} \mathrm{yr}^{-1}\right)$ was calculated as follows:

$$
\mathrm{ON}_{\mathrm{AR}}=\frac{\rho . \partial \mathrm{Z} / \partial \mathrm{t}}{\partial \mathrm{t}} * \mathrm{C} * 10 \text {, }
$$

where $\rho$ is the dry bulk density $\left(\mathrm{g} \mathrm{cm}^{-3}\right), \mathrm{Z}$ is the depth $(\mathrm{cm}), \mathrm{t}$ denotes time (years), and $\mathrm{C}$ is the concentration of ON $\left(\mathrm{mg} \mathrm{g}^{-1}\right)$.

\subsection{Auxiliary data presentation}

Data on nitrogen fertilizer use and land area under construction were collected from the National Bureau of Statistics (http://data.cnki.net/). We downloaded the temperature and rainfall data from the Chinese Meteorological Data Sharing Service System (http://cdc.cma.gov.cn). The concentrations of TN and TP in the overlying water were collected from previous studies that conducted in-situ measurements (He et al., 2015; Zhou et al., 2016).

\subsection{STIRPAT model}


The STIRPAT (stochastic impacts by regression on population, affluence and technology) model, originally named IPAT, was proposed by Ehrlich and Holdren (1971) and was used to describe the effects of human activities on the environment in 1994 (Dietz, 1994). To overcome various model weaknesses, the model was reformulated using reasonable equations and became the STIRPAT model. As all variables were in logarithmic form to facilitate estimation and hypothesis testing, they modified the STIRPAT model to a logarithmic regression model (York et al., 2003), thereby developing the current model:

$\operatorname{Ln}\left(\mathrm{I}_{\mathrm{it}}\right)=\mathrm{a}+\sum \mathrm{a}_{\mathrm{it}} \operatorname{Ln}\left(\mathrm{F}_{\mathrm{it}}\right)+\varepsilon_{\mathrm{it}}(6)$

where $F_{\text {it }}$ represents relevant factors (e.g., population size, gross domestic product, and technology), $a$ is a constant, $e$ is an error term, and $a_{i t}$ denotes the elasticity of the corresponding parameters, wherein the elasticity value indicates that a $1 \%$ increase in $\mathrm{F}$ induces a certain percent change in I. In some studies, the model can be extended by adding other factors with a logical correlation to a specific environment (Wang et al., 2013).On this basis, to comprehensively examine the relevant factors driving ON loads entering the lake, the extended STIRPAT model was amended by adding meteorological factors (e.g., temperature). In this study, an ordinary least squares regression was employed after testing that there was no multicollinearity in the variables. If multi-collinearity occurred, a ridge regression would have been selected to increase the significance of the model.

\section{Results}

\subsection{ON concentration and accumulation rate}

The concentration of ON increased gradually over the study period. Specifically, the ON contents in DC-S, DC-E, and DC-N increased from $595.5 \mathrm{mg} \mathrm{kg}^{-1}$ to $6140.3 \mathrm{mg} \mathrm{kg}^{-1}, 347.1 \mathrm{mg} \mathrm{kg}^{-1}$ to $2848.2 \mathrm{mg} \mathrm{kg}^{-1}$, and $297.8 \mathrm{mg} \mathrm{kg}^{-1}$ to $2752.4 \mathrm{mg} \mathrm{kg}^{-1}$, respectively (Fig. 2A). Overall, the ON contents increased from $375.5 \pm$ $231.6 \mathrm{mg} \mathrm{kg}^{-1}$ in 1900 to $4536.8 \pm 1734.5 \mathrm{mg} \mathrm{kg}^{-1}$ in 2012 over a 112-year period. Significant increases in ON were observed after 1960 in DC-N and DC-S, and after 1980 in DC-E. Since 1960, the mean values of ON declined in the order: DC-S $\left(2630.2 \pm 1604.6 \mathrm{mg} \mathrm{kg}^{-1}\right)>$ DC-N $\left(1574.8 \pm 977.7 \mathrm{mg} \mathrm{kg}^{-1}\right)>$ DC-E $(1083.9$ $\left.\pm 912.5 \mathrm{mg} \mathrm{kg}^{-1}\right)$. The highest ON content $\left(6140.3 \mathrm{mg} \mathrm{kg}^{-1}\right)$ was observed in DC-S in 2000.

The $\mathrm{ON}_{\mathrm{AR}}$ gradually decreased with vertical depth. The $\mathrm{ON}_{\mathrm{AR}}$ showed almost no change before the $1970 \mathrm{~s}$, with mean values of $0.101 \mathrm{mg} \mathrm{cm}^{-2} \mathrm{yr}^{-1}$, but significantly increased after, with mean values of $0.302 \mathrm{mg}$ $\mathrm{cm}^{-2} \mathrm{yr}^{-1}$ (Fig. 2B). The highest $\mathrm{ON}_{\mathrm{AR}}$ was observed on the surface in all three sediment cores. After the 1970 s, the increase in the $\mathrm{ON}_{\mathrm{AR}}$ followed the order: $\mathrm{DC}-\mathrm{N}\left(0.375 \mathrm{mg} \mathrm{cm}^{-2} \mathrm{yr}^{-1}\right)>\mathrm{DC}-\mathrm{S}\left(0.283 \mathrm{mg} \mathrm{cm}^{-2} \mathrm{yr}^{-}\right.$ $\left.{ }^{1}\right)>$ DC-E $\left(0.242 \mathrm{mg} \mathrm{cm}^{-2} \mathrm{yr}^{-1}\right)$.

\subsection{Distributions of $n$-alkanes}

The variations in the $n$-alkanes characteristics of vertical depth were different in each of the three sediment cores (Fig. 3). The total concentrations of $n$-alkanes $\left(n-\mathrm{C}_{12}\right.$ to $n$ - $\left.\mathrm{C}_{34}\right)$ (TNA) were $22,209.6 \mathrm{ng} \mathrm{g}^{-1}$ 
$\left(9,022.2 \mathrm{ng} \mathrm{g}^{-1}\right.$ to $\left.61,959.6 \mathrm{ng} \mathrm{g}^{-1}\right), 10,617.5 \mathrm{ng} \mathrm{g}^{-1}\left(4,719.4 \mathrm{ng} \mathrm{g}^{-1}\right.$ to $\left.18,240.1 \mathrm{ng} \mathrm{g}^{-1}\right)$, and $15,276.9 \mathrm{ng}$ $\mathrm{g}^{-1}\left(5,769.9 \mathrm{ng} \mathrm{g}^{-1}\right.$ to $\left.28,090.9 \mathrm{ng} \mathrm{g}^{-1}\right)$ in DC-S, DC-N, and DC-E, respectively. For DC-S, the aliphatic hydrocarbon fractions were mainly from allochthonous-derived long-chain $n-\mathrm{C}_{27}$ to $n-\mathrm{C}_{31}$ alkanes in the surface $10 \mathrm{~cm}$, and then became autochthonous-derived short-chain $n-\mathrm{C}_{17}$ alkanes at $10-20 \mathrm{~cm}$. Meanwhile, DC-E exhibited bimodal behavior, with long-chain $n-\mathrm{C}_{27}$ to $n-\mathrm{C}_{31}$ alkanes and short-chain $n-\mathrm{C}_{17}$ alkanes on its surface, which declined with depth. After $1980(0-10 \mathrm{~cm})$, short-and mid-chain $n$-alkanes ( $n-\mathrm{C}_{14}$ to $n-\mathrm{C}_{25}$ ), especially $n-\mathrm{C}_{17}$, tended to be larger contributors, suggesting that the sources of organic matter varied (between mixed planktonic and terrestrial sources) and that the phytoplankton contribution increased from the bottom to the top of the sediment core. For DC-N, only one clear peak with short-chain $n-\mathrm{C}_{17}$ alkanes was found on the surface, which gradually decreased with depth. In the lower section (1906-1965 AD), the TNA value was relatively low, exhibiting a bimodal distribution $\left(n-\mathrm{C}_{16}\right.$ and $\left.n-\mathrm{C}_{18}\right)$. It then increased gradually from $13 \mathrm{~cm}$ to $0 \mathrm{~cm}$, which corresponds to 1965 and 2012, respectively. The $n$ alkanes distribution indicated an abundance of short-chain $n$-alkanes $\left(n-\mathrm{C}_{14}\right.$ to $n$ - $\left.\mathrm{C}_{20}\right)$ with a peak value at $C_{17}$. Overall, before 1958, the TNA values were very low, whereas after $1958(16 \mathrm{~cm})$, the TNA values increased and the $n$-alkanes distribution showed an abundance of short-chain $n$-alkanes $\left(n-\mathrm{C}_{14}\right.$ to $\left.n-\mathrm{C}_{20}\right)$ with a peak value at $\mathrm{C}_{17}$, indicating that the $n$-alkanes in the north came predominantly from bacteria or fungal lipids, and fossil fuel combustion.

\section{Discussion}

\subsection{Sources of organic nitrogen}

In general, the sources of ON in lake sediments are very complex, but mainly include autochthonous (e.g., algae, aquatic plants, and animals) and allochthonous (e.g., soil erosion, atmospheric deposition, and living or aquaculture wastewater) sources. Therefore, the sources of $\mathrm{ON}$ in the three sediment cores varied. In the DC-S core, the correlations between the short-chain $n$-alkanes and $\mathrm{ON}$ at the upper part of the core (1-14 cm, 2012-1981) were negative, whereas they were positive at the bottom core (15-32 cm, 19781903) (Table 1). In addition, the correlations were positive between $\mathrm{ON}$ and the mid- and long-chain $n$ alkanes. The $\mathrm{CPI}_{2}$ values ranged from 1.20 to 2.95 with mean of 1.87 (Fig. 4), which indicated a greater input from microorganisms, recycled OM, and petroleum (Choi and Lee, 2013; Liu and Liu, 2016). Meanwhile, the Paq values were relatively high $(0.54 \pm 0.10$, mean value \pm standard deviation), indicating that the $\mathrm{ON}$ was primarily derived from allochthonous microorganisms and floating aquatic plants in the southern lake (Han and Calvin, 1969; Jeng, 2006). More recently, the ON content was mostly contributed to by sources different from those associated with short-chain $n$-alkanes. This is consistent with the fact that a large amount of forest land has been replaced by farmland in the last three decades, as farmland has a higher risk of soil erosion as a result of frequent tillage (Quinton et al., 2010; Huang et al., 2014). In addition, it was estimated that the proportion of nitrogen fertilizer utilization by crops was only $30-40 \%$ (Ju et al., 2009), suggesting that a large amount of nitrogen fertilizer directly discharged into southern Dianchi Lake. 
Table 1

Linear correlation between organic nitrogen (ON) concentration and different carbon number $n$-alkanes $(P$ $<0.01$ for all values)

\begin{tabular}{|c|c|c|c|c|c|c|c|c|c|}
\hline & $\mathrm{C}_{16}$ & $\mathrm{C}_{17}$ & $\mathrm{C}_{18}$ & $\mathrm{C}_{23}$ & $\mathrm{C}_{24}$ & $\mathrm{C}_{25}$ & $\mathrm{C}_{27}$ & $\mathrm{C}_{29}$ & $\mathrm{C}_{31}$ \\
\hline DC-S $(1-14 \mathrm{~cm})$ & -0.796 & -0.356 & -0.661 & 0.244 & 0.148 & 0.232 & 0.262 & 0.026 & 0.227 \\
\hline DC-S $(15-32 \mathrm{~cm})$ & 0.871 & 0.871 & 0.864 & 0.721 & 0.505 & 0.471 & 0.435 & 0.408 & 0.203 \\
\hline DC-E & 0.891 & 0.942 & 0.951 & 0.290 & 0.064 & 0.164 & 0.594 & 0.533 & 0.207 \\
\hline DC-N & 0.879 & 0.932 & 0.908 & 0.895 & 0.791 & 0.549 & 0.678 & 0.592 & 0.189 \\
\hline
\end{tabular}

In DC-E, ON exhibited a positive correlation with short-chain $n$-alkanes, which are mainly from bacteria and algae (Table 1) (Mead et al., 2005; Fang et al., 2014). In addition, the relevant Paq $(0.37 \pm 0.05), \mathrm{CPI}_{1}(0.66$ $\pm 0.14)$, and $\mathrm{CPI}_{2}(1.51 \pm 0.34)$ values for $\mathrm{DC}$-E were lower than those in the other cores, suggesting that $n$ alkanes in the east of Dianchi Lake were derived from a mixed organic matter source of submerged and floating aquatic plants and terrigenous higher plants (Fig. 4) (Wang et al., 2014; Sawada et al., 2020). This is consistent with previous cluster analysis results, which showed that flower and vegetable cultivation with high fertilization increased the contribution of exogenous nitrogen to eastern Dianchi Lake (Huang et al., 2017a). The correlation between $\mathrm{ON}$ and the mid- and short-chain $n$-alkanes was most significant in DC-N, especially for $\mathrm{C}_{17}\left(\mathrm{R}^{2}=0.87\right)$. Thus, the main sources of $\mathrm{ON}$ were short-chain $n$-alkanes, which are mainly derived from endogenous biomass and allochthonous origins (Wang et al., 2014; Zhan et al., 2020). In addition, the mean value of $\mathrm{CPI}_{1}(0.91 \pm 0.14)$ was close to 1 with the preference for $n-\mathrm{C}_{17}$, indicating that the short-chain $n$-alkanes were mainly derived from endogenous algae and phytoplankton (Hockun et al., 2016; Liu and Liu, 2016). Further, the C/N ratio increased from $6.6 \pm 2.9$ to $12.4 \pm 3.4$ in the last four decades, suggesting that the sources of organic matter changed from primarily algae to human activities in recent years. The north side of Dianchi Lake is near Kunming City, and is thus heavily influenced by human activities, such as sewage and industrial effluent processes (He et al., 2015).

Previous studies have indicated that eutrophication was first observed in northern Dianchi Lake in 1970 as a result of the rapid economic development and urbanization of Kunming City (Huang et al., 2014; Chen et al., 2020). Overall, endogenous algae and phytoplankton are the primary contributors to the source of ON in northern Dianchi Lake.

\subsection{Influencing factors on the organic nitrogen burial}

Dianchi Lake is a typical plateau-type hydrostatic lake with a long water residence, in which exogenous pollutants flowing into the lake are easily deposited. A previous study indicated that only approximately $20 \%$ of pollutants are discharged via Dianchi Lake processes while the rest remain in the sediment, allowing them to be easily released into the overlying water again (He et al., 2015). This phenomenon is one of the reasons for the higher ON content (294-6140 $\mathrm{mg} \mathrm{kg}^{-1}$ ) in Dianchi Lake sediment than in other eutrophic lake sediments, such as Chaohu Lake (195-1076 $\mathrm{mg} \mathrm{kg}^{-1}$ ) and Taihu Lake (278-4687 mg kg- 
${ }^{1}$ ) (Yu et al., 2018; Wu et al., 2019). In addition, the specific conditions of the sediment core sampling region affect $\mathrm{ON}$ burial. For instance, one of the reasons the $\mathrm{ON}$ concentration in the DC-E sediment is the lowest of the observed cores is because the water depth in eastern Dianchi Lake is less than $30 \mathrm{~cm}$, causing it to be easily affected by the prevailing southwest winds (Fig. 2A) (Chen et al., 2007). Therefore, the formation type and hydrological characteristics of lakes are some of the most important factors affecting $\mathrm{ON}$ burial.

A previous study on Taihu Lake indicated that increasing precipitation intensity and frequency could cause more nutrients to flow into the lake (Paerl et al., 2011). In this study, the annual precipitation gradually decreased over the last three decades, according to the Kunming Meteorological Bureau record (Fig. 5A). Moreover, the discharge of industrial wastewater from Kunming City decreased from 151.5 million tons in 1990 to 31.2 million tons in 2010 as a result of strict water pollution management (Huang et al., 2014; He et al., 2015). However, the $\mathrm{ON}_{\mathrm{AR}}$ values of the Dianchi Lake sediment cores significantly increased from $0.369 \mathrm{mg} \mathrm{kg}^{-1}$ in 2000 to $0.759 \mathrm{mg} \mathrm{kg}^{-1}$ in 2010 (Fig. 2B), suggesting they might be affected by other environmental conditions, such as temperature. It has been confirmed that increasing temperature enhances gross primary productivity, as well as terrestrial and aquatic vegetation via photosynthetic rate acceleration and growing season extension (Larsen et al., 2011; Chen et al., 2020). The results obtained are consistent with those of previous studies, revealing that TP decreased in Dianchi Lake between 2000 and 2010, when algal blooms began to occur frequently (Fig. 5C) (Wang et al., 2020).

In addition to climate change, human activities (e.g., tillage, fertilization, and land-use change) are also considered to be important factors influencing $\mathrm{ON}$ burial in lacustrine sediments. The average $O \mathrm{~N}_{\mathrm{AR}}$ increased 2.7-4.6 times from 1995 to 2012 in the three sediment cores (Fig. 2B), which corresponds to chemical nitrogen fertilizer use, which increased from $50.9 \times 10^{3} \mathrm{Mg}$ to $90.9 \times 10^{3} \mathrm{Mg}$ (Fig. 5B). It has been reported that inappropriate fertilization would result in a high risk of nitrogen fertilizer loss into the lake via precipitation runoff and leaching, which is then utilized rapidly by algal and aquatic plants (Gao et al., 2015). In addition, the $\mathrm{ON}$ content from crop residue could increase because of nitrogen fertilizer application, which indirectly stimulates the $\mathrm{ON}_{\mathrm{AR}}$ burial in the lake sediments. Moreover, the construction land increased sharply from $137 \mathrm{~km}^{2}$ (1995) to $842 \mathrm{~km}^{2}$ (2012) in the Dianchi Lake basin (Fig. 5B), which was accompanied by a large amount of topsoil erosion due to the disruption of the Earth's surface (Guzman et al., 2013; Huang et al., 2017a). A previous study revealed that fluvial sediment yield increased 1.85 times, as compared with the background value, because of the agricultural land use in western China's rivers (Schmidt et al., 2018). Therefore, high-intensity human activities, such as agricultural production and urbanization, significantly stimulate the $\mathrm{ON}_{\mathrm{AR}}$.

\subsection{Elasticity of driving factors}

The results summarized in Table 2 were strongly related to sedimentary ON variations, including temperature, rainfall, nitrogen fertilizer, and construction land. On this basis, we explored the factors that have a major impact on sedimentary ON variations in different regions of Dianchi Lake using the STIRPAT model (Fig. 6). Overall, it is obvious that temperature could significantly stimulate the $\mathrm{ON}_{\mathrm{AR}}$ in all three 
sediment cores, especially in DC-S, where in a $1 \%$ increase in temperature resulted in a $33.1 \%$ increase in the $\mathrm{ON}_{\mathrm{AR}}$. This demonstrates that warmer temperatures improve biological productivity and promote nitrogen deposition in lakes by increasing phytoplankton and microbial activity (Larsen et al., 2011; Chen et al., 2020). In addition, rainfall significantly increased the $O N_{A R}$ values in the DC-S and DC-N cores, whereas the $\mathrm{ON}_{\mathrm{AR}}$ was only weakly reduced in DC-E. This is because the depth of eastern Dianchi Lake is too shallow to deposit $\mathrm{ON}$, which may cause precipitation to have a dilution effect on the ON intensity. Conversely, the higher $\mathrm{ON}$ content as a result of rainfall occurred in $\mathrm{DC}-\mathrm{N}$, wherein sewage and domestic pollutants easily flow into the lake via precipitation because of the high proportion of construction land in Kunming City. However, the elasticity of chemical nitrogen fertilizer was higher than that of other factors in DC-E, in which a $1 \%$ increase in the amount of nitrogen fertilizer increased the ON burial by $106.1 \%$. In this region, flower and vegetable cultivation is the main land use type, which consumes a large proportion of chemical nitrogen fertilizer (Huang et al., 2014; Gao et al., 2015). Furthermore, the elasticities of the construction land area were negative but insignificant for DC-E (Fig. 6). In general, increasing urban construction land could cause effluent decrease because the urban built area significantly reduces the density of urban pollution and dilutes the concentration of pollutant discharge over a given period (Rickson, 2014).

Table 2

Estimated results for organic nitrogen (ON) models in three regions considering four factors

\begin{tabular}{|c|c|c|c|c|c|c|c|c|}
\hline & Temperature & Rainfall & $\begin{array}{l}\text { Nitrogen } \\
\text { fertilizer }\end{array}$ & $\begin{array}{l}\text { Construction } \\
\text { Land Area }\end{array}$ & $\mathrm{TN}$ & TP & $\mathrm{R}^{2}$ & $F$ \\
\hline $\begin{array}{l}\text { DC- } \\
\text { S }\end{array}$ & $0.331^{*}$ & $0.501^{\star *}$ & $0.343^{\star \star \star}$ & $-0.142^{*}$ & 0.053 & -0.113 & 0.593 & 2.673 \\
\hline $\begin{array}{l}\text { DC- } \\
\text { E }\end{array}$ & 0.230 & $-0.007^{\star}$ & $1.061^{\star \star \star}$ & -0.085 & 0.282 & 0.025 & 0.866 & 11.846 \\
\hline $\begin{array}{l}\text { DC- } \\
N\end{array}$ & $0.308^{*}$ & $0.573^{\star \star}$ & 0.198 & $-0.024^{*}$ & 0.027 & $0.135^{*}$ & 0.422 & 2.338 \\
\hline
\end{tabular}

\section{Conclusions}

The ON content and burial in the sediments of Dianchi Lake showed significant spatial and temporal variations. Specifically, the $\mathrm{ON}$ content declined in the order: $\mathrm{DC}-\mathrm{S}>\mathrm{DC}-\mathrm{N}>\mathrm{DC}-\mathrm{E}$, while the $\mathrm{ON}_{\mathrm{AR}}$ followed the order: DC-N > DC-S > DC-E. In addition, ON content significantly increased in the 1960s, whereas the $\mathrm{ON}_{\mathrm{AR}}$ increased beginning in the 1980s. The ON sources were found to be both allochthonous and autochthonous, and exhibited significant spatial and temporal variations. In addition to the characteristics of lakes, climate change (temperature and rainfall) and human activities (nitrogen fertilization and urbanization) are also important factors affecting the $\mathrm{ON}_{\mathrm{AR}}$. In particular, over the past four decades, the dominant contribution of human activities to the $\mathrm{ON}_{\mathrm{AR}}$ was mainly in the east and south of Dianchi Lake, 
whereas in the last two decades, climate change was the main contributor to the $\mathrm{ON}_{\mathrm{AR}}$ in the south and north of Dianchi Lake. Moreover, $1 \%$ increases in temperature and nitrogen fertilizer could increase the $\mathrm{ON}_{\mathrm{AR}}$ by $73.8-86.2 \%$ and $73.2-151.3 \%$, respectively, in all sediments, whereas a $1 \%$ increase in construction area could reduce the amount of ON buried by $2.4-14.2 \%$. In summary, climate change and human activities determine the spatial and temporal $\mathrm{ON}_{\mathrm{AR}}$ in Dianchi Lake. Further, climate change and human activities contribute to the eutrophication of Dianchi Lake, which both directly and indirectly affects the $\mathrm{ON}_{\mathrm{AR}}$. Therefore, more research is needed to understand the effect of the relationships between climate change and human activity on $\mathrm{ON}_{\mathrm{AR}}$ in lakes.

\section{Declarations}

\section{Ethics approval and consent to participate}

Not applicable

\section{Consent for publication}

Not applicable

\section{Availability of data and materials}

The research data are available on request: zhangzhigang840620@126.com.

\section{Competing interests}

We declare that we do not have any commercial or associative interest that represents a conflict of interest in connection with the work submitted.

\section{Authors' contributions}

T.H., C.C.H., and Z.G.Z. designed the experiments. Y.L., Q.L.J., H.Y., and T.H. carried out the experiments and performed the analyses. T.H., Y.L., C.C.H., and Z.G.Z. substantially contributed to interpreting the results and writing the paper.

\section{Acknowledgements}

This work was funded by the National Natural Science Foundation of China (Grant No. 41971009 , 41503054, 41971286 and 41773097), and the Youth Top Talent funded by Nanjing Normal University. We would like to thank Editage (www.editage.cn) for English language editing.

\section{References}

1. Anderson, N.J., Bennion, H., Lotter, A.F., 2014. Lake eutrophication and its implications for organic carbon sequestration in Europe. Global Change Biol. 20, 2741-2751. 
2. Anderson, N.J., Dietz, R.D., Engstrom, D.R., 2013. Land-use change, not climate, controls organic carbon burial in lakes. Proceedings of the Royal Society B-Biological Sciences 280(1769):20131278.doi:https://doi.org/10.1098/rspb.2013.1278

3. Chen, Q.Y., Ni, Z.K., Wang, S.R., Guo, Y., Liu, S.R., 2020. Climate change and human activities reduced the burial efficiency of nitrogen and phosphorus in sediment from Dianchi Lake, China. J. Clean Prod. 274.122839. doi:https://doi.org/10.1016/j.jclepro.2020.122839

4. Chen, Y.C., Tang, L., Zhang, D.G., Li, J., Zhou, J., Guan, X.P., 2007. Spatial and Temporal Dynamic Variation of Nitrogen in Sediment of Dianchi Lake. Soils 39, 879-883.

5. Choi, Y.J., Lee, S.Y., 2013. Microbial production of short-chain alkanes. Nature 502, 571-574.

6. Conley, D.J., Paerl, H.W., Howarth, R.W., Boesch, D.F., Seitzinger, S.P., Havens, K.E., Lancelot, C., Likens, G.E., 2009. Controlling Eutrophication: Nitrogen and Phosphorus. Science 323, 1014-1015.

7. Dietz, T.R., E.A, 1994. Rethinking the environmental impacts of population, Affluence and technology. Human Ecology Review 1(Weeh 1986), 277-300.

8. Downing, J.A., Cole, J.J., Middelburg, J.J., Striegl, R.G., Duarte, C.M., Kortelainen, P., Prairie, Y.T., Laube, K.A., 2008. Sediment organic carbon burial in agriculturally eutrophic impoundments over the last century. Global Biogeochem. Cy. 22. doi: https://doi.org/10.1029/2006GB002854.

9. Ehrlich, P.R., Holdren, J.P., 1971. Impact of population growth. Science (New York, N.Y.) 171, 12121217.

10. Elser, J.J., Bracken, M.E.S., Cleland, E.E., Gruner, D.S., Harpole, W.S., Hillebrand, H., Ngai, J.T., Seabloom, E.W., Shurin, J.B., Smith, J.E., 2007. Global analysis of nitrogen and phosphorus limitation of primary producers in freshwater, marine and terrestrial ecosystems. Ecol. Lett. 10, 1135-1142.

11. Fang, J., Wu, F., Xiong, Y., Li, F., Du, X., An, D., Wang, L., 2014. Source characterization of sedimentary organic matter using molecular and stable carbon isotopic composition of n-alkanes and fatty acids in sediment core from Lake Dianchi, China. Sci. Total Environ. 473, 410-421.

12. Ficken, K.J., Li, B., Swain, D.L., Eglinton, G., 2000. An n-alkane proxy for the sedimentary input of submerged/floating freshwater aquatic macrophytes. Org. Geochem. 31, 745-749.

13. Fortino, K., Whalen, S.C., Smoak, J.M., 2016. Patterns in the percent sediment organic matter of arctic lakes. Hydrobiologia 777, 149-160.

14. Fowler, D., Pyle, J.A., Raven, J.A., Sutton, M.A., 2013. The global nitrogen cycle in the twenty-first century: introduction. Philos. T. R. Soc. B 368.20130165. DOI10.1098/rstb.2013.0165.

15. Galloway, J.N., Townsend, A.R., Erisman, J.W., Bekunda, M., Cai, Z., Freney, J.R., Martinelli, L.A., Seitzinger, S.P., Sutton, M.A., 2008. Transformation of the nitrogen cycle: Recent trends, questions, and potential solutions. Science 320, 889-892.

16. Galman, V., Rydberg, J., de-Luna, S.S., Bindler, R., Renberg, I., 2008. Carbon and nitrogen loss rates during aging of lake sediment: Changes over 27 years studied in varved lake sediment. Limnol. Oceanogr. 53, 1076-1082.

17. Gao, W., Howarth, R.W., Swaney, D.P., Hong, B., Guo, H.C., 2015. Enhanced N input to Lake Dianchi Basin from 1980 to 2010: Drivers and consequences. Sci. Total Environ. 505, 376-384. 
18. Guzman, G., Quinton, J.N., Nearing, M.A., Mabit, L., Gomez, J.A., 2013. Sediment tracers in water erosion studies: current approaches and challenges. J. Soil Sediment 13, 816-833.

19. Han, J., Calvin, M., 1969. Hydrocarbon distribution of algae and bacteria, and microbiological activity in sediments. P. Natl. Acad. Sci. USA 64, 436-443.

20. He, J., Xu, X., Yang, Y., Wu, X., Wang, L., Li, S., Zhou, H., 2015. Problems and effects of comprehensive management of water environment in Lake Dianchi. Journal of Lake Sciences 27, 195-199.

21. Heathcote, A.J., Anderson, N.J., Prairie, Y.T., Engstrom, D.R., del Giorgio, P.A., 2015. Large increases in carbon burial in northern lakes during the Anthropocene. Nature Communications 6.10016.

DOI10.1038/ncomms10016.

22. Hockun, K., Mollenhauer, G., Ho, S.L., Hefter, J., Ohlendorf, C., Zolitschka, B., Mayr, C., Luecke, A., Schefuss, E., 2016. Using distributions and stable isotopes of n-alkanes to disentangle organic matter contributions to sediments of Laguna Potrok Aike, Argentina. Org. Geochem. 102, 110-119.

23. Huang, C., Yang, H., Li, Y., Zhang, M., Lv, H., Zhu, A.X., Yu, Y., Luo, Y., Huang, T., 2017a. Quantificational effect of reforestation to soil erosion in subtropical monsoon regions with acid red soil by sediment fingerprinting. Environ. Earth. Sci. 76.D0110.1007/s12665-016-6349-z.

24. Huang, C., Yao, L., Zhang, Y., Huang, T., Zhang, M., Zhu, A.X., Yang, H., 2017b. Spatial and temporal variation in autochthonous and allochthonous contributors to increased organic carbon and nitrogen burial in a plateau lake. Sci. Total Environ. 603, 390-400.

25. Huang, C.C., Wang, X.L., Yang, H., Li, Y.M., Wang, Y.H., Chen, X., Xu, L.J., 2014. Satellite data regarding the eutrophication response to human activities in the plateau lake Dianchi in China from 1974 to 2009. Sci. Total Environ. 485, 1-11.

26. Jeng, W.-L., 2006. Higher plant n-alkane average chain length as an indicator of petrogenic hydrocarbon contamination in marine sediments. Mar. Chem. 102, 242-251.

27. Jiang, Q., Li, S., Chen, Z., Huang, C., Wu, W., Wan, H., Hu, Z., Han, C., Zhang, Z., Yang, H., Huang, T., 2020. Disturbance mechanisms of lacustrine organic carbon burial: Case study of Cuopu Lake, Southwest China. Sci. Total. Environ. 746.140615. DOl10.1016/j.scitotenv.2020.140615.

28. Ju, X.T., Xing, G.X., Chen, X.P., Zhang, S.L., Zhang, L.J., Liu, X.J., Cui, Z.L., Yin, B., Christie, P., Zhu, Z.L., Zhang, F.S., 2009. Reducing environmental risk by improving $\mathrm{N}$ management in intensive Chinese agricultural systems. P. Natl. Acad. Sci. USA 106, 3041-3046.

29. Larsen, S., Andersen, T., Hessen, D.O., 2011. Climate change predicted to cause severe increase of organic carbon in lakes. Global Change Biol. 17, 1186-1192.

30. Leithold, E.L., Blair, N.E., Wegmann, K.W., 2016. Source-to-sink sedimentary systems and global carbon burial: A river runs through it. Earth-Science Reviews 153, 30-42.

31. Liu, H., Liu, W., 2016. n-Alkane distributions and concentrations in algae, submerged plants and terrestrial plants from the Qinghai-Tibetan Plateau. Org. Geochem. 99, 10-22.

32. Mead, R., Xu, Y.P., Chong, J., Jaffe, R., 2005. Sediment and soil organic matter source assessment as revealed by the molecular distribution and carbon isotopic composition of n-alkanes. Org. Geochem. $36,363-370$. 
33. Paerl, H.W., Xu, H., McCarthy, M.J., Zhu, G., Qin, B., Li, Y., Gardner, W.S., 2011. Controlling harmful cyanobacterial blooms in a hyper-eutrophic lake (Lake Taihu, China): The need for a dual nutrient ( $N$ \& P) management strategy. Water Res. 45, 1973-1983.

34. Quinton, J.N., Govers, G., Van Oost, K., Bardgett, R.D., 2010. The impact of agricultural soil erosion on biogeochemical cycling. Nat. Geosci. 3, 311-314.

35. Rickson, R.J., 2014. Can control of soil erosion mitigate water pollution by sediments? Sci. Total Environ. 468, 1187-1197.

36. Sanchez-Cabeza, J.A., Ruiz-Fernandez, A.C., 2012. Pb-210 sediment radiochronology: An integrated formulation and classification of dating models. Geochim. Cosmochim. Ac. 82, 183-200.

37. Sawada, K., Ono, M., Nakamura, H., Tareq, S.M., 2020. Reconstruction of Holocene Optimum paleoclimatic variations using long-chain n-alkanes and alkenones in sediments from Dabusu Lake, northeastern China. Quaternary International 550, 27-38.

38. Schmidt, A.H., Gonzalez, V.S., Bierman, P.R., Neilson, T.B., Rood, D.H., 2018. Agricultural land use doubled sediment loads in western China's rivers. Anthropocene 21, 95-106.

39. Smith, J.N., 2001. Why should we believe Pb-210 Sediment geochronologies? Journal of Environmental Radioactivity 55, 121-123.

40. Wang, B.C., Yang, J., Jiang, H.C., Zhang, G.J., Dong, H.L., 2019. Chemical composition of n-alkanes and microbially mediated n-alkane degradation potential differ in the sediments of Qinghai-Tibetan lakes with different salinity. Chem. Geol. 524, 37-48.

41. Wang, J.H., Wang, Y.N., Dao, G.H., Du, J.S., Han, Y.P., Hu, H.Y., 2020. Decade-long meteorological and water quality dynamics of northern Lake Dianchi and recommendations on algal bloom mitigation via key influencing factors identification. Ecol. Indic. 115.106425. DOI10.1016/j.ecolind.2020.106425.

42. Wang, N., Zong, Y.Q., Brodie, C.R., Zheng, Z., 2014. An examination of the fidelity of n-alkanes as a palaeoclimate proxy from sediments of Palaeolake Tianyang, South China. Quaternary International 333, 100-109.

43. Wang, P., Wu, W.S., Zhu, B.Z., Wei, Y.M., 2013. Examining the impact factors of energy-related CO2 emissions using the STIRPAT model in Guangdong Province, China. Appl. Energ. 106, 65-71.

44. Wu, T.F., Qin, B.Q., Brookes, J.D., Yan, W.M., Ji, X.Y., Feng, J., 2019. Spatial distribution of sediment nitrogen and phosphorus in Lake Taihu from a hydrodynamics-induced transport perspective. Sci. Total Environ. 650, 1554-1565.

45. York, R., Rosa, E.A., Dietz, T., 2003. STIRPAT, IPAT and ImPACT: analytic tools for unpacking the driving forces of environmental impacts. Ecol. Econ. 46, 351-365.

46. Yu, Q.B., Wang, F., Yan, W.J., Zhang, F.S., Lv, S.C., Li, Y.Q., 2018. Carbon and Nitrogen Burial and Response to Climate Change and Anthropogenic Disturbance in Chaohu Lake, China. Int. J. Env. Res. Pub. He. 15.DOI10.3390/ijerph15122734.

47. Zhan, S., Wu, J.L., Wang, J.Z., Jing, M., 2020. Distribution characteristics, sources identification and risk assessment of n-alkanes and heavymetals in surface sediments, Tajikistan, Central Asia. Sci. Total Environ. 709.136278. DOI10.1016/j.scitotenv.2019.136278. 
48. Zhou, Q., Zhang, Y., Lin, D., Shan, K., Luo, Y., Zhao, L., Tan, Z., Song, L., 2016. The relationships of meteorological factors and nutrient levels with phytoplankton biomass in a shallow eutrophic lake dominated by cyanobacteria, Lake Dianchi from 1991 to 2013. Environ. Sci. Pollut. R. 23, 1561615626.

49. Zhou, Y., Liu, Y., 2016. Does population have a larger impact on carbon dioxide emissions than income? Evidence from a cross-regional panel analysis in China. Appl. Energ. 180, 800-809.

\section{Figures}




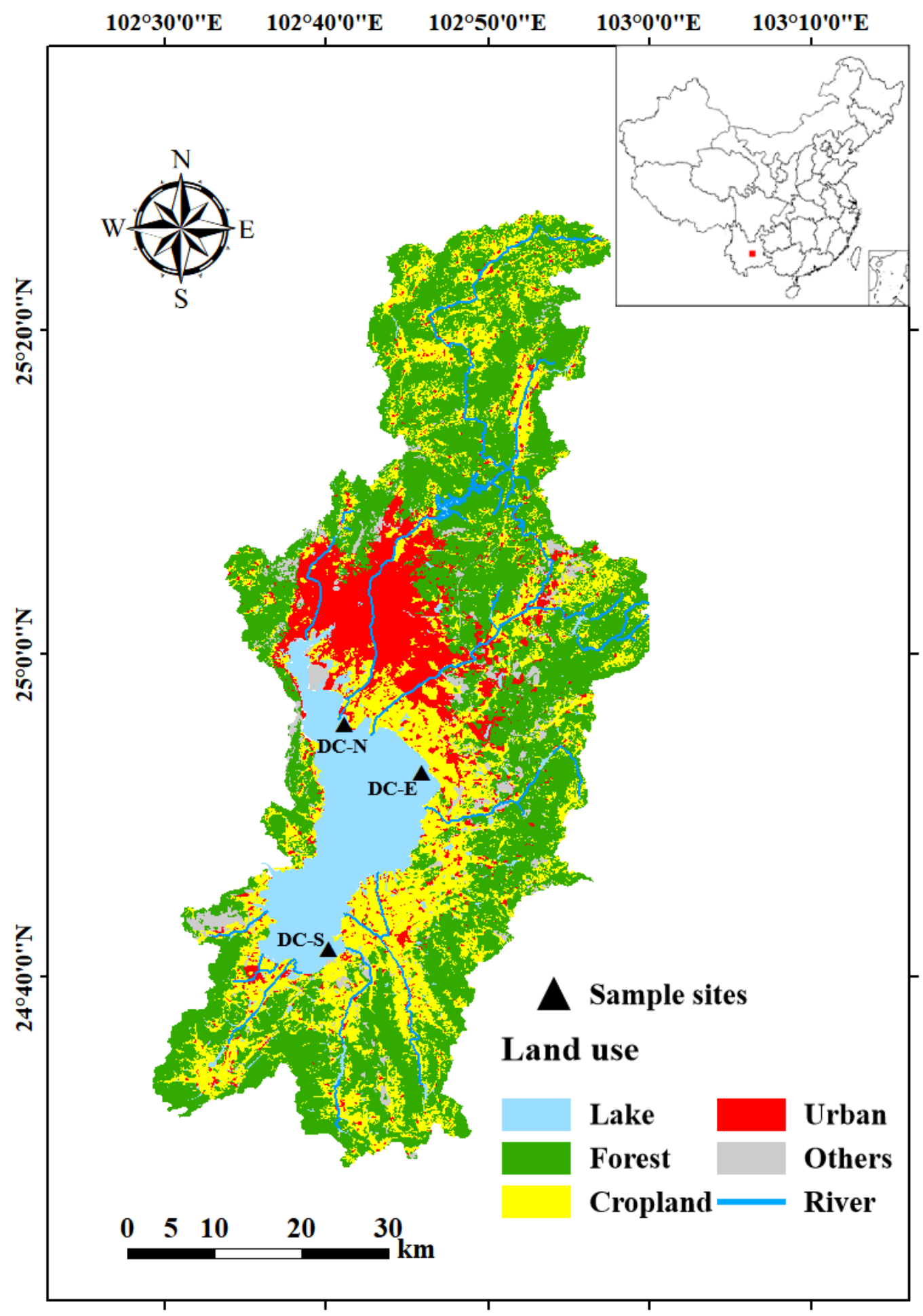

Figure 1

Study area and location of sampling sites 


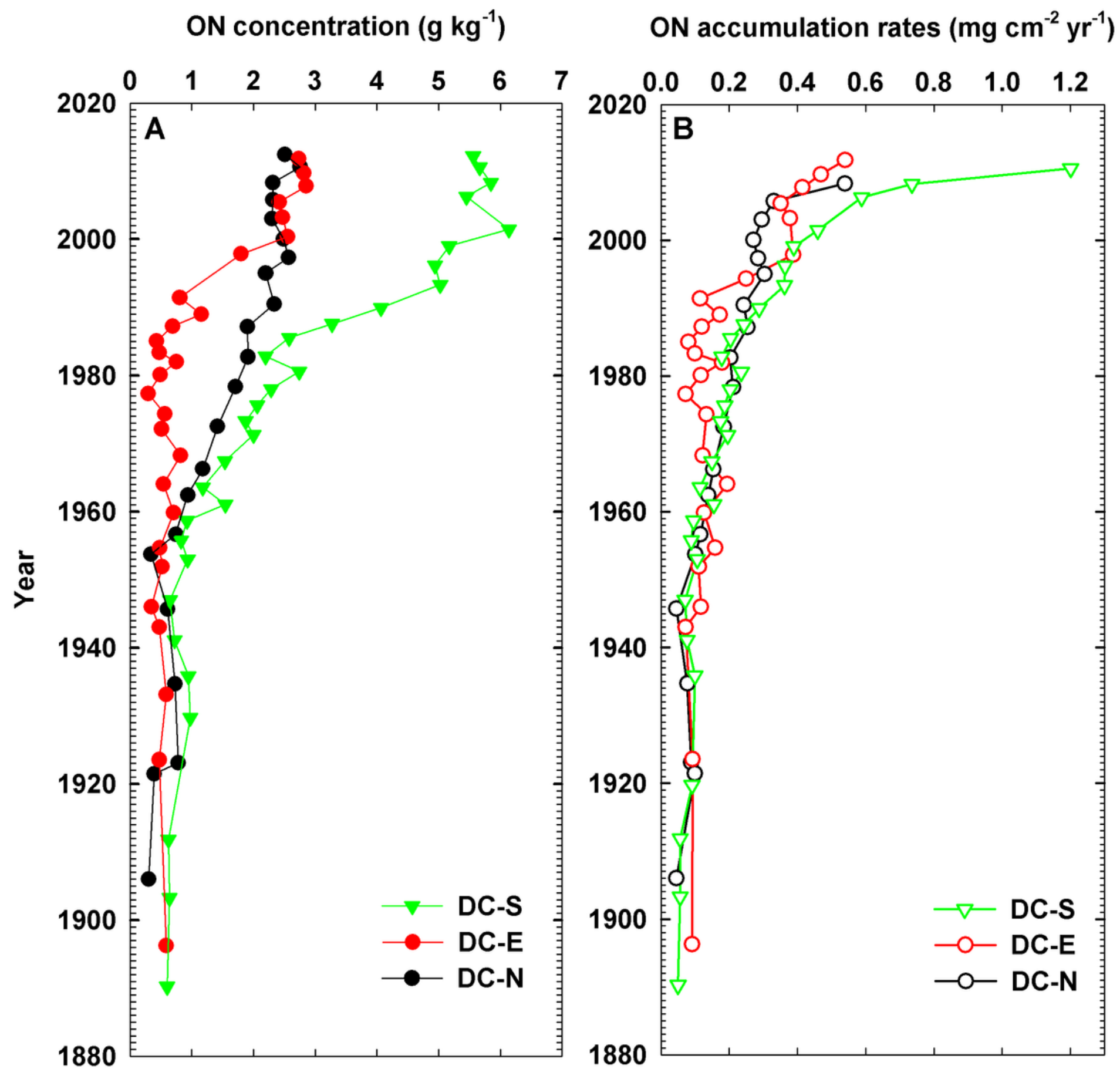

ON accumulation rates $\left(\mathrm{mg} \mathrm{cm}^{-2} \mathrm{yr}^{-1}\right)$

Figure 2

Profiles of the organic nitrogen (ON) concentration and organic nitrogen accumulation rates (ONAR) for three sediment cores in Dianchi Lake 

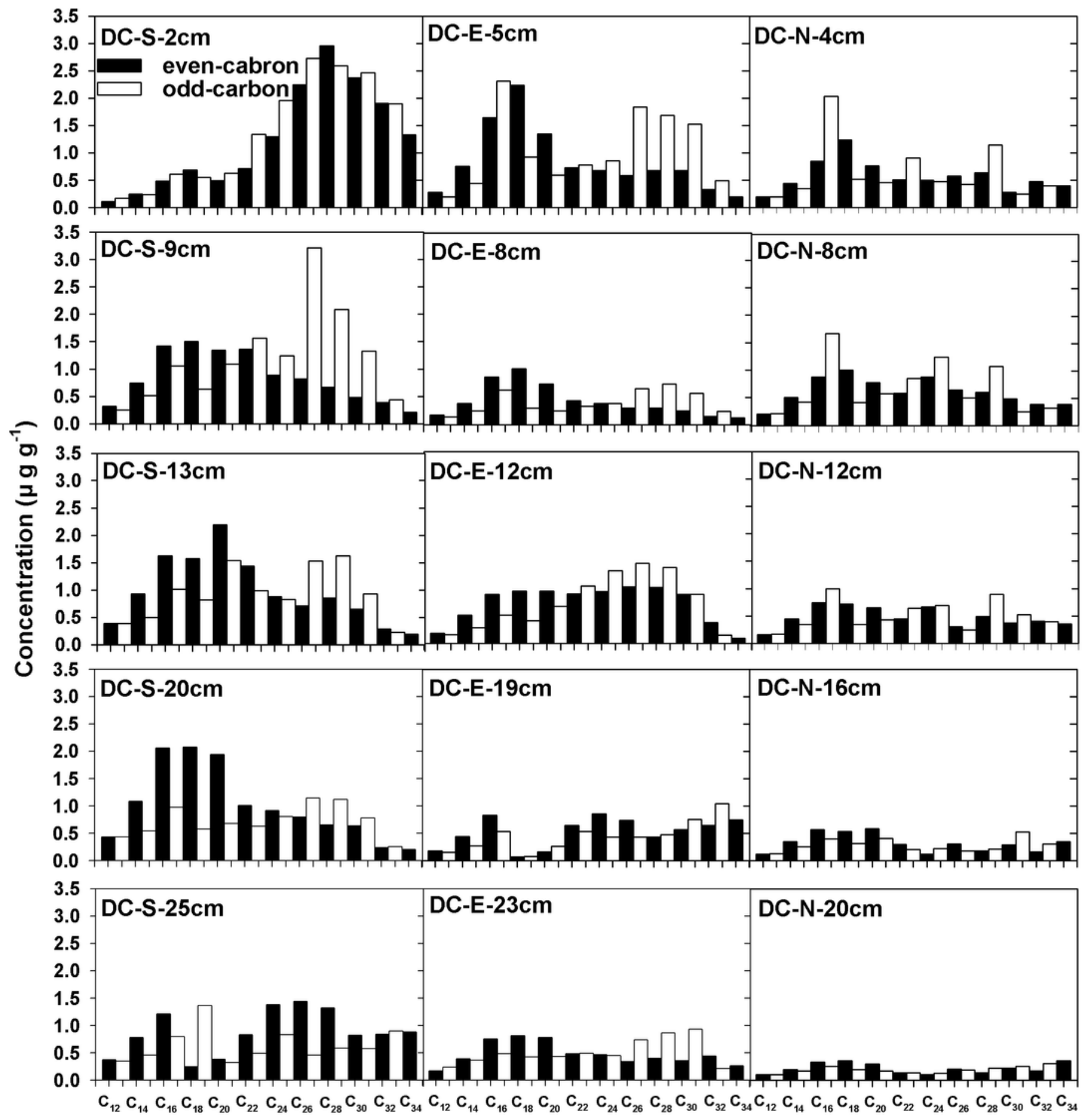

Figure 3

Distribution profiles of $n$-alkanes in several representative samples at different depths for three sediment cores in Dianchi Lake 

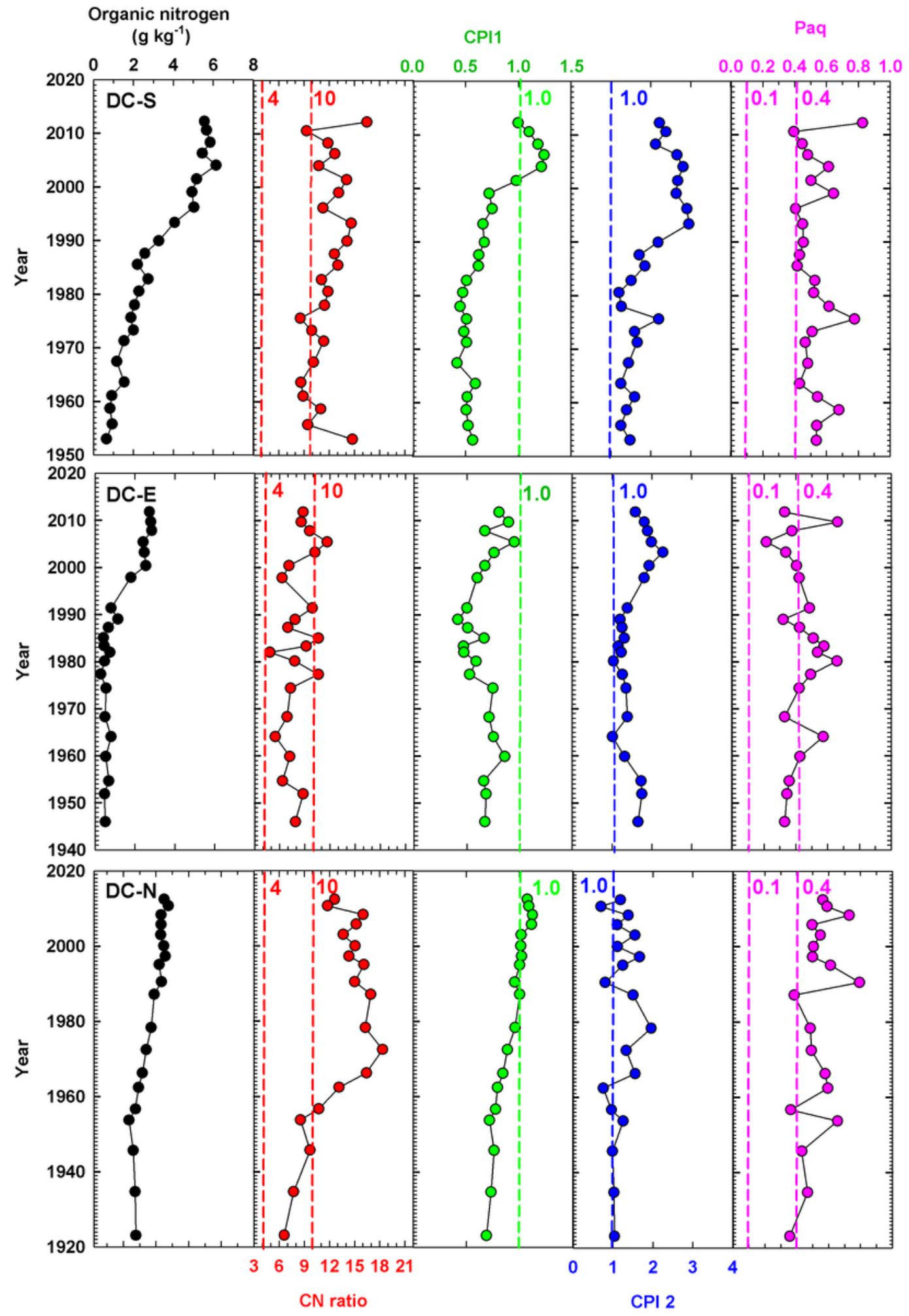

Figure 4

Organic nitrogen ( $\mathrm{ON}$ ) concentration, $\mathrm{C} / \mathrm{N}$ ratio, and $\mathrm{n}$-alkane source diagnostic ratio profiles for three

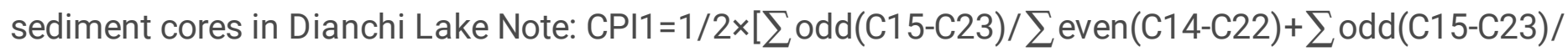

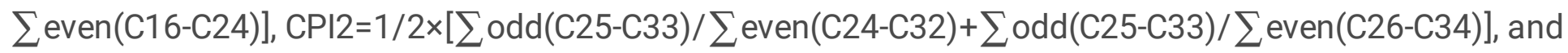
$\mathrm{Paq}=(\mathrm{C} 23+\mathrm{C} 25) /(\mathrm{C} 23+\mathrm{C} 25+\mathrm{C} 29+\mathrm{C} 31)$. The $\mathrm{C} / \mathrm{N}$ ratio varied from 4 to 10 , indicatingthat theorganic 
matter (OM) mainly originated from phytoplankton and algae. When the $\mathrm{C} / \mathrm{N}$ ratiowas $\geq 12$, the $\mathrm{OM}$ was mainly from terrestrial higher plants. Paq $<0.1,0.1$
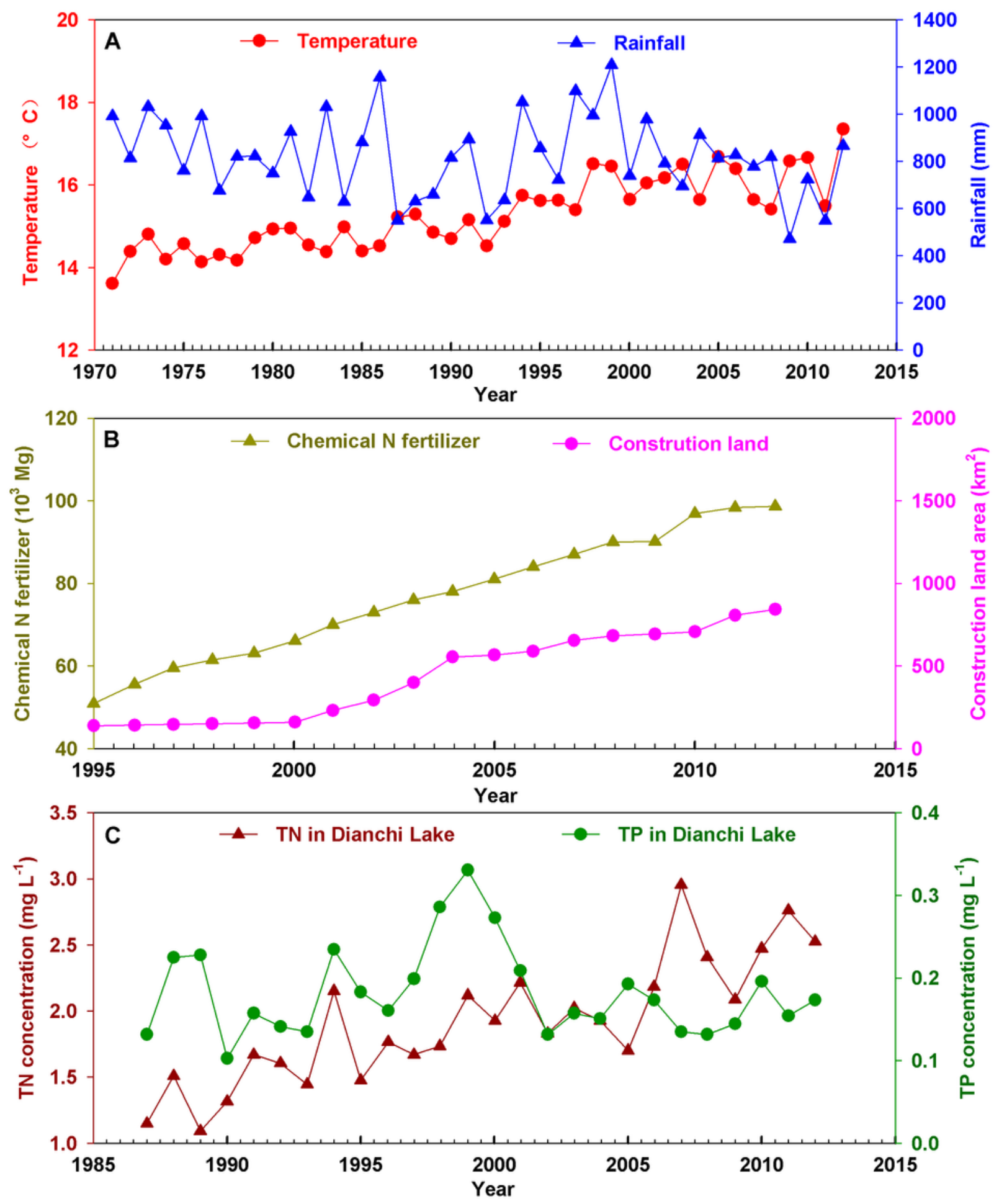

Figure 5

(A) Historical variations of climate in Kunming City, (B) socioeconomic status in Kunming City, and (C) water nutrient factors in Dianchi lake 


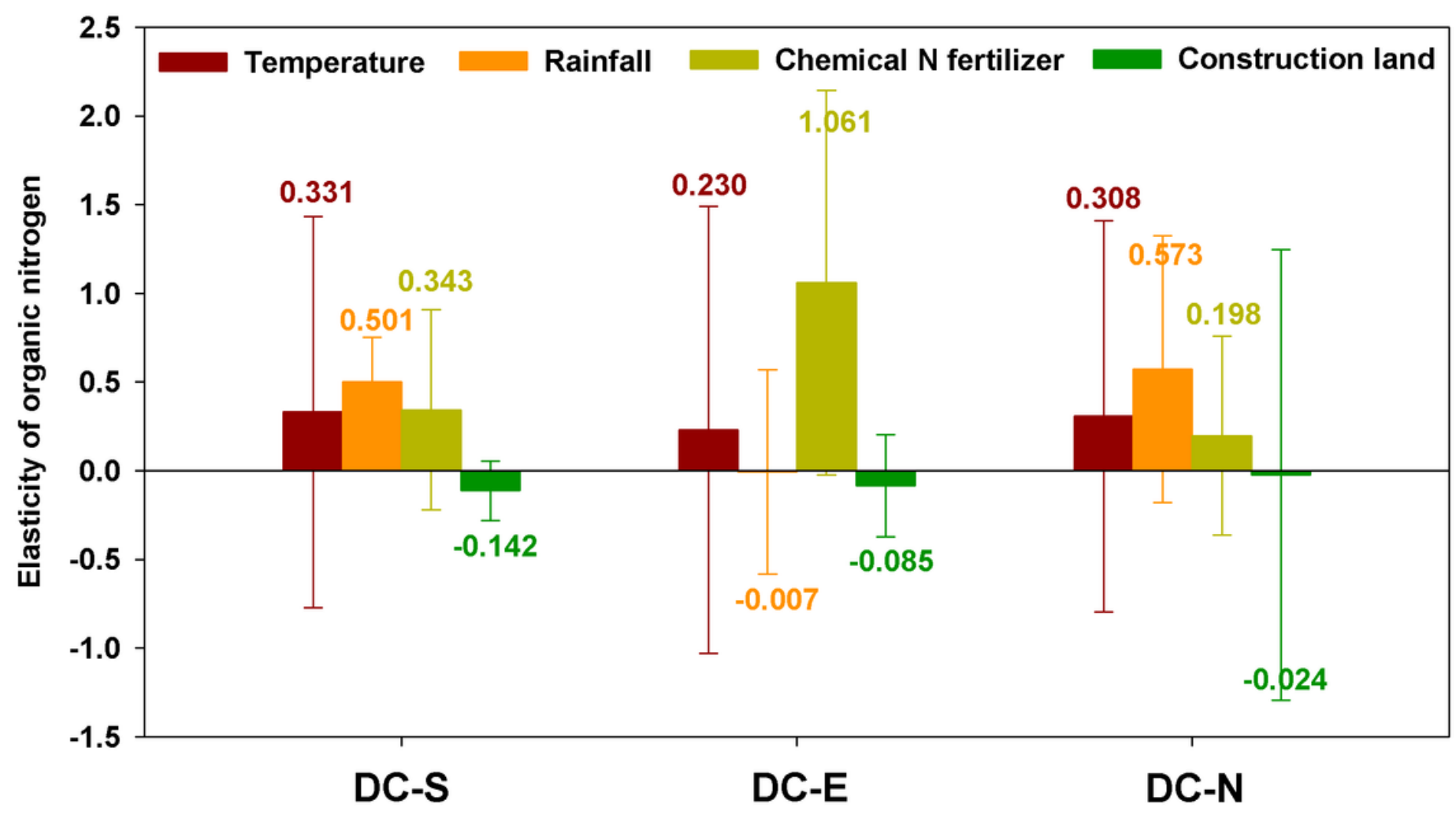

Figure 6

Elasticities of organic nitrogen (ON) contents regarding temperature, rainfall, nitrogen fertilizer and construction land. Bars denote the estimated elasticity for ON while error bars show $95 \%$ confidence interval values obtained using the stochastic impacts by regression on population, affluence, and technology (STIRPAT) model. Elasticities denote what a $1 \%$ increase in the influencing factors would induce the $\mathrm{ON}$ content (\%) 